\title{
41. SANDSTONE AND SILTSTONE BEDS OVERLYING CONGLOMERATE AT DEEP SEA DRILLING PROJECT SITE 439, JAPAN TRENCH
}

\author{
Kantaro Fujioka, Ocean Research Institute, University of Tokyo, Tokyo, Japan \\ Eiichi Honza, Geological Survey of Japan, Tsukuba, Japan \\ and \\ Noriyuki Nasu, Ocean Research Institute, University of Tokyo, Tokyo, Japan
}

\begin{abstract}
Massive sandstone and siltstone beds with many shallow-water megafossils overlie acidic volcanic conglomerates at DSDP Site 439. Smear-slides, thin sections from coarse fractions, and heavy minerals of the sandstone and siltstone beds were analyzed. The sandstones and siltstones are very rich in lithic fragments and are classified as lithic arenite and (or) lithic wacke. Hornblende and clinopyroxene are abundant, and zircon is present in most of the examined samples. The proportions of sandstone, chert, and volcanic rock in the coarse fraction are variable, but fragments of clastic rocks and cherts are predominant. Plagioclase crystals of volcanic-rock origin, such as highly zoned plagioclase and very fine, euhedral, lath-shaped plagioclase, are frequently observed. Metamorphic-rock fragments and metamorphic minerals are also observed. Thus, the provenance of the sandstone and siltstone beds appears to have been a slightly mature island arc, the Oyashio ancient landmass, consisting of clastic sediments and metamorphic and volcanic rocks.
\end{abstract}

\section{INTRODUCTION}

Sedimentary Unit 5 of DSDP Sites 438 and 439 comprises massive sandstones and siltstones with many fossil mollusks overlying a conglomerate containing acidic volcanic rocks. We consider these nearshore sandstones to have been transported from a nearby source region, the Oyashio ancient landmass (von Huene, Nasu, 1978). These sandstones are rich in lithic fragments and are classified as lithic arenite and (or) lithic wacke. Usually, it is useful to estimate provenance from heavy-mineral assemblages in sediments. In these sandstone beds, the amounts of heavy minerals are low compared with those of lithic fragments; therefore, lithic fragments must be used to indicate the provenance of the sediments.

\section{GENERAL DESCRIPTION OF SANDSTONES AND SILTSTONES IN UNIT 5}

Figure 1 shows the stratigraphic column of Sites 438 and 439 (see Site Report 438-439). Seven lithologic units have been identified.

Lithologic Unit 5 consists of extremely homogeneous, massive, well-sorted sandstones and siltstones. Sedimentary structures are extremely rare, and articulated bivalves, well-preserved gastropods, and fragments of various mollusks are characteristic. The sandstone and siltstone are calcite-cemented only near the contact with Unit 6, although articulated bivalves often have calcitecemented sand fillings. Carbonized wood is also found. Cores 22 to 25 contain benthic foraminifers distinct from the early Miocene assemblages. These assemblages are thought to be of late-Oliocene age, and the paleodepth deduced from the benthic-foraminifera assemblages is considered to have been between 50 and 150 meters, a shelf environment (Keller, this volume). ${ }^{40} \mathrm{Ar} /{ }^{39} \mathrm{Ar}$ dates from the acidic volcanic rocks of conglomerate underlying the sandstone and siltstone average $21.4 \pm 1.0 \mathrm{~m} . \mathrm{y}$. (earliest Miocene; Yanagisawa, this volume). There is a slight discrepancy between the paleontological age and the radiometric age.

\section{SMEAR-SLIDE OBSERVATIONS}

Thirty smear slides were carefully examined with a petrographic microscope, aboard ship and after the cruise. The proportions of sand, silt, and clay, and mineralogic constituents are listed in Table 1 . The clay component in Unit 5 never exceeds 50 per cent and is slightly lower than in Unit 4. However, smear slides are not the best way to estimate grain size.

Dominant constituents of sandstone and siltstone of Unit 5 are quartz, plagioclase, and lithic fragments, and the total of the three components is nearly 50 per cent of the sediments. Quartz plus plagioclase is always at least one-third of the sediment, reaching 70 per cent in some cases. Quartz grains are anhedral and many small dusty inclusions are observed in some grains. In metamorphosed quartz grains such features are frequently observed; therefore, some of the quartz grains may be derived from metamorphic rocks.

Various shapes and grain sizes of plagioclase are observed throughout this formation. Highly zoned plagioclase fragments are frequently observed, and the grain size of this type of plagioclase is usually very large. Rare- 

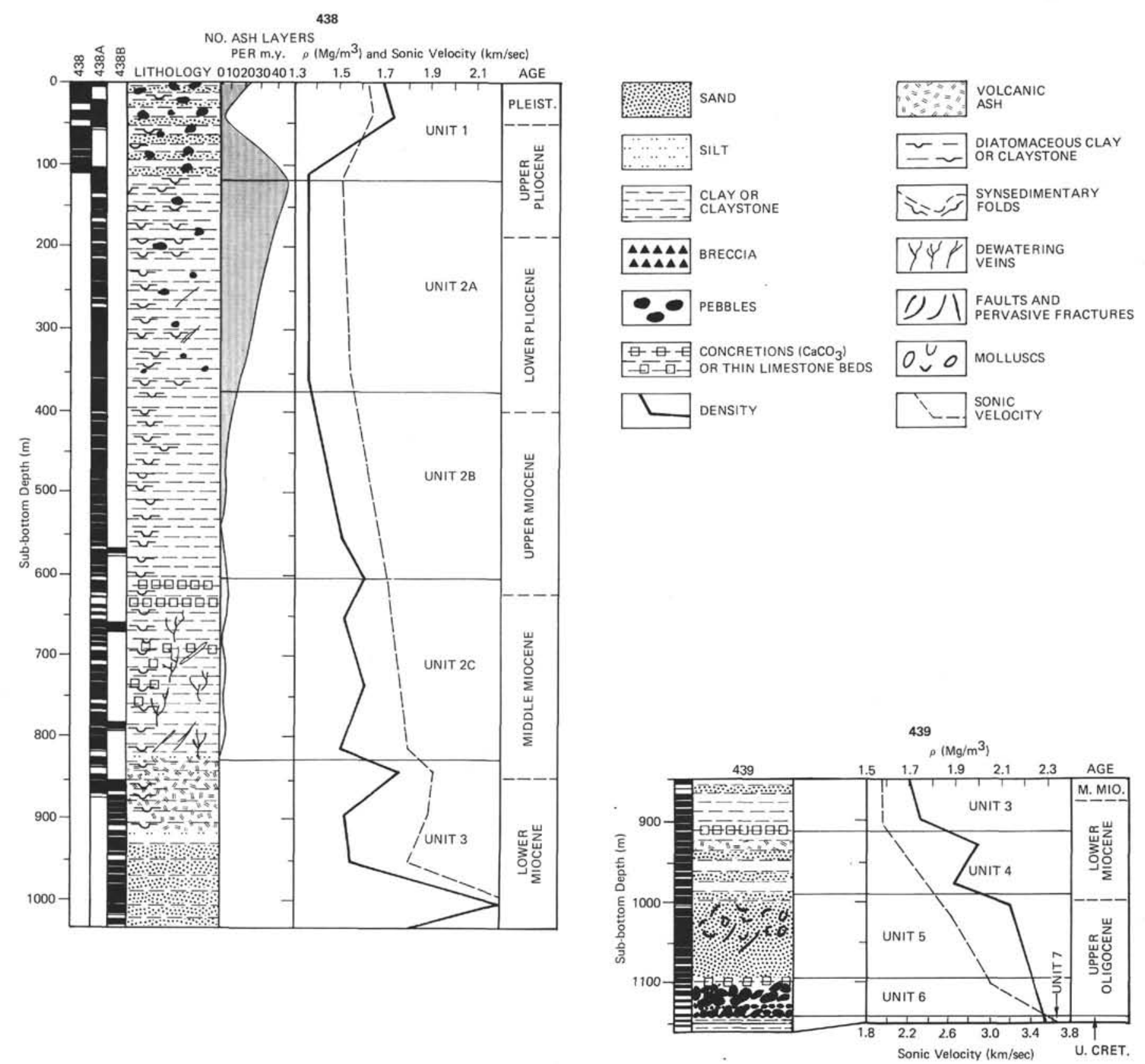

Figure 1. Stratigraphic column and lithologic units at Sites 438 and 439. Unit 5 lies between 993.5 and 1098.0 meters below the sea floor, corresponding to Sections 22-2 to 32-1 of Hole 439 (von Huene et al., 1978).

ly, euhedral, zoned plagioclases are found. This type of plagioclase may be derived from plutonic rocks and (or) phenocrysts of volcanic rocks. The other type of plagioclase is very fine-grained, euhedral, and lath-shaped. This type of plagioclase is frequently observed throughout this formation. The origin of this type of plagioclase is probably in the groundmass of porphyritic volcanic rocks.

These observations suggest that most of the plagioclase is derived from volcanic rocks, such as those of the underlying conglomerate bed. Volcanic glass is a significant minor constituent of the sandstone and siltstone. In this unit, brown glass having a high refractive index predominates over clear, white glass of acidic composition.
The brown glass has a basaltic-andesite and (or) andesitic composition. Acidic glass is rare. Biogenic components such as diatoms, foraminifers, radiolarians, and nannofossils are very rare. This supports interpretation that the sandstone and siltstone were deposited in very shallow water, near the surf zone. Carbonate minerals are locally present in very high amounts in Sections $24-4$, $30-1$, and 30-2. In these samples, large calcite grains and very fine-grained carbonates are observed.

\section{HEAVY MINERALS}

Heavy minerals are very important as a key to provenance of sedimentary rocks. Total amounts of heavy minerals measured from the smear slides are low, usually 
TABLE 1

Constituents of Sandstones and Siltstones of Units 4 and 5, Site 439

\begin{tabular}{|c|c|c|c|c|c|c|c|c|c|c|}
\hline $\begin{array}{c}\text { Sample } \\
\text { (interval in } \mathrm{cm} \text { ) }\end{array}$ & Sand & Silt & Clay & Quartz & $\begin{array}{l}\text { Feld- } \\
\text { spar }\end{array}$ & $\begin{array}{c}\text { Heavy } \\
\text { Minerals }\end{array}$ & Glass & $\begin{array}{l}\text { Glau- } \\
\text { conite }\end{array}$ & $\begin{array}{c}\text { Biogenic } \\
\text { Components }\end{array}$ & Clay \\
\hline $439-20-1,70$ & 3 & 25 & 72 & 42 & 4 & 1 & 5 & - & 3 & 41 \\
\hline $20-1,111$ & 48 & 30 & 22 & 28 & 10 & 8 & 9 & 2 & tr. & 18 \\
\hline $20-1,115-117$ & 55 & 30 & 15 & 30 & 25 & 2 & 1 & tr. & - & 12 \\
\hline $21-1,82$ & 8 & 22 & 70 & 35 & 5 & 1 & 3 & 1 & - & 28 \\
\hline $21-1,96-97$ & 65 & 30 & 5 & 35 & 20 & 3 & 2 & - & - & 5 \\
\hline $21-1,106$ & 25 & 30 & 45 & 55 & 10 & 5 & 1 & 1 & - & 28 \\
\hline $21-2,109-111$ & 65 & 25 & 10 & 28 & 20 & 3 & 5 & tr. & - & 5 \\
\hline $22-2,93$ & 50 & 30 & 20 & 40 & 5 & 2 & 1 & 1 & - & 19 \\
\hline $22-2,95$ & 35 & 40 & 25 & 38 & 30 & tr. & - & 1 & - & 19 \\
\hline $22-3,72-75$ & 55 & 25 & 20 & 35 & 25 & tr. & - & - & - & 10 \\
\hline $22-5,138$ & 50 & 17 & 33 & 50 & 11 & - & - & 1 & 1 & 13 \\
\hline $22-6,7-10$ & 33 & 59 & 8 & 30 & 16 & 2 & 1 & 1 & - & 8 \\
\hline $23-1,27-29$ & 38 & 35 & 27 & 32 & 22 & 1 & tr. & 1 & - & 16 \\
\hline $23-1,118$ & 45 & 25 & 30 & 30 & 10 & - & 6 & 1 & - & 16 \\
\hline $23-3,10-12$ & 40 & 35 & 25 & 40 & 25 & 1 & 1 & 1 & - & 4 \\
\hline $24-1,95$ & 30 & 50 & 20 & 30 & 20 & tr. & 2 & 2 & - & 15 \\
\hline $24-1,103$ & 10 & 60 & 30 & 30 & 20 & - & 1 & 2 & - & 18 \\
\hline $24-4,65$ & 10 & 50 & 40 & 30 & 10 & - & - & - & tr. & 15 \\
\hline $24-4,73$ & 10 & 60 & 30 & 30 & 10 & tr. & - & tr. & - & - \\
\hline $24-5,141-143$ & 10 & 55 & 35 & 32 & 20 & tr. & tr. & tr. & - & 16 \\
\hline $25-3,74$ & 1 & 60 & 39 & 25 & 20 & - & - & - & - & 25 \\
\hline $25-4,8-11$ & 22 & 48 & 30 & 50 & 25 & 1 & 1 & 1 & - & - \\
\hline $25-5,83$ & 3 & 60 & 37 & 30 & 15 & 7 & - & tr. & - & 35 \\
\hline $26-2,92$ & 5 & 75 & 20 & 40 & 25 & - & 5 & tr. & - & 20 \\
\hline $26-3,77-79$ & 65 & 25 & 10 & 28 & 20 & 1 & tr. & 1 & - & - \\
\hline $26-4,70$ & 15 & 60 & 25 & 45 & 25 & 3 & - & tr. & - & 20 \\
\hline $26-6,1-4$ & 25 & 50 & 25 & 30 & 27 & 2 & 1 & tr. & - & 25 \\
\hline $26-6,95$ & 30 & 45 & 25 & 35 & 23 & - & 7 & - & - & 20 \\
\hline $27-2,56$ & 15 & 70 & 15 & 50 & 20 & 3 & - & - & - & 10 \\
\hline $27-2,148-150$ & 50 & 35 & 15 & 30 & 25 & 1 & 2 & tr. & - & 5 \\
\hline $27-3,10-12$ & 25 & 25 & 50 & 35 & 28 & 1 & tr. & tr. & - & - \\
\hline $28-1,56$ & 50 & 30 & 20 & 27 & 15 & 2 & 1 & 2 & - & 15 \\
\hline $28-2,49-51$ & 50 & 30 & 20 & 40 & 22 & 1 & 2 & tr. & - & - \\
\hline $28-3,89$ & 50 & 30 & 20 & 30 & 15 & - & tr. & - & - & 15 \\
\hline $29-1,55$ & 50 & 30 & 20 & 30 & 15 & 1 & tr. & tr. & - & 15 \\
\hline $29-2,74-77$ & 50 & 32 & 18 & 28 & 20 & tr. & - & tr. & - & 9 \\
\hline $29-2,91$ & 50 & 30 & 20 & 30 & 15 & 2 & 3 & tr. & - & 15 \\
\hline $30-1,87$ & 50 & 30 & 20 & 25 & 10 & 1 & 2 & - & - & 15 \\
\hline $30-2,-140$ & 18 & 52 & 30 & 32 & 16 & tr. & - & - & - & 32 \\
\hline $31-3,68-70$ & 38 & 42 & 20 & 25 & 15 & 1 & - & - & - & 14 \\
\hline
\end{tabular}

less than 5 per cent. Heavy minerals observed in the smear slides and thin sections are listed in Table 1 as a plus symbol. They are hornblende (brown and green), clinopyroxene (chiefly augite), orthopyroxene (hypersthene), biotite, epidote, zircon, garnet, opaque oxide, and muscovite. Miki and Takahashi (this volume) report tourmaline and diopside in addition to the above-named minerals. The most abundant heavy mineral observed in this study is hornblende (brown and green). Some hornblendes show a nearly euhedral shape and are very fresh. Augite, hypersthene, and biotite are also rather frequently observed. These minerals may be derived chiefly from volcanic rocks. Some plagioclases may be of volcanicrock origin. Therefore, judging from the mineralogy of the sediments, materials derived from volcanic rocks may be abundant.

Zircon, garnet, and tourmaline are also observed. According to Miki and Takahashi (this volume), the small elongation ratio of zircon, mostly less than 2.0 , suggests a sedimentary source.

Epidote, one of the metamorphic minerals, was also found in small amounts. Fine-grained muscovite with kink bands was also found. Judging from the heavy minerals, the provenance of the sediments embraced sedimentary, volcanic, and metamorphic rocks.

\section{LITHIC FRAGMENTS}

In order to determine the provenance of sediments of Unit 5, precise observations of lithic fragments were carried out in smear slides and special thin sections. The special thin sections were made by this method: first, sediments were softly crushed, then the fine fraction was decanted. The remaining coarse fraction was impregnated with an epoxy resin, and then the thin sections were made.

In the thin sections thus prepared, the percentage of lithic fragments reaches about 70 per cent or more, and we can easily determine rock type and lithology of the fragments. In smear slides, about half the lithic fragments are transparent under the microscope and we can likewise determine lithology of the lithic fragments by this method.

The proportions of quartz, plagioclase, and lithic fragments and the type of sandstone and percentages of rock 
TABLE 1 - Continued

\begin{tabular}{|c|c|c|c|c|c|c|c|c|c|c|}
\hline $\begin{array}{c}\text { Car- } \\
\text { bonate }\end{array}$ & $\begin{array}{c}\text { Lithic } \\
\text { Fragments }\end{array}$ & $\begin{array}{l}\text { Horn- } \\
\text { blende }\end{array}$ & $\begin{array}{c}\text { Clino- } \\
\text { pyroxene }\end{array}$ & $\begin{array}{l}\text { Ortho- } \\
\text { pyroxene }\end{array}$ & Biotite & Epidote & Zircon & Garnet & $\begin{array}{c}\text { Opaque } \\
\text { Minerals }\end{array}$ & Other \\
\hline 4 & - & + & - & - & - & - & + & - & - & - \\
\hline- & 25 & + & + & - & - & - & - & - & + & - \\
\hline- & 30 & + & + & - & - & + & - & - & + & + \\
\hline- & - & + & - & - & - & - & - & - & - & - \\
\hline- & 35 & + & + & + & + & + & - & - & + & - \\
\hline- & - & + & - & - & - & - & - & - & - & - \\
\hline- & 45 & + & + & - & + & - & + & - & + & + \\
\hline 2 & 30 & - & - & - & - & - & + & - & - & - \\
\hline- & 20 & + & - & - & - & - & + & - & + & - \\
\hline- & 30 & + & - & - & - & + & + & - & + & - \\
\hline 5 & 12 & - & - & - & - & - & - & - & - & - \\
\hline- & 40 & + & + & - & - & - & - & - & + & + \\
\hline- & 28 & + & - & - & + & - & + & - & + & - \\
\hline 2 & 35 & - & - & - & - & - & - & - & - & - \\
\hline- & 28 & + & - & - & + & - & + & - & + & - \\
\hline- & 25 & - & - & - & - & - & - & - & - & - \\
\hline- & 25 & - & - & - & - & - & - & - & - & - \\
\hline 10 & 35 & - & - & - & - & - & - & - & - & - \\
\hline 23 & 35 & - & - & - & - & - & - & - & - & - \\
\hline 2 & 30 & - & - & - & - & - & - & - & - & + \\
\hline- & 25 & - & - & - & - & - & - & - & - & - \\
\hline- & 22 & + & - & - & - & - & - & - & + & + \\
\hline 5 & - & - & - & - & + & - & - & - & - & - \\
\hline 5 & - & - & - & - & - & - & - & - & - & - \\
\hline - & 50 & + & + & - & - & - & + & - & + & - \\
\hline 3 & - & + & - & - & - & - & - & - & - & - \\
\hline- & 15 & + & + & - & - & - & - & - & + & + \\
\hline 2 & - & + & - & - & - & - & - & - & - & - \\
\hline 15 & - & - & - & - & - & - & - & - & - & - \\
\hline- & 35 & + & - & - & - & - & - & - & + & + \\
\hline 1 & 35 & + & - & - & - & - & - & - & - & + \\
\hline 10 & 20 & - & - & - & - & - & - & - & - & - \\
\hline- & 32 & + & + & + & - & - & + & - & + & + \\
\hline 3 & 32 & - & - & - & - & - & - & - & - & - \\
\hline 5 & 31 & - & - & - & - & - & - & - & - & - \\
\hline- & 43 & - & - & - & - & - & + & - & + & + \\
\hline- & 35 & - & - & - & - & - & - & - & - & - \\
\hline 20 & 30 & - & - & - & - & - & - & - & - & - \\
\hline 10 & 10 & - & - & - & - & - & - & + & + & + \\
\hline- & 45 & + & + & - & - & - & - & - & + & + \\
\hline
\end{tabular}

types observed in lithic fragments are listed in Table 2 and 3. All the lithic fragments lack orthopyroxene. To classify the sandstones of this unit, data were plotted on a quartz-feldspar-lithic fragment triangular diagram. Nomenclature of sandstone is from Okada's (1971) classification. The term wacke denotes sandstone in which clay constitutes more than 15 per cent; arenite denotes sandstone in which clay constitutes less than 15 per cent. In Figure 2, the sandstones plot mostly in the fields of lithic arenite and feldspathic wacke and (or) lithic wacke. Samples without lithic fragments are not plotted in this figure, because there is a possibility that this component was not counted in shipboard smear-slide observations. Such samples may plot in the lithic-arenite field.

The largest lithic fragment examined is $1.68 \mathrm{~mm}$ (Table 3). The lithic fragments are all angular to subangular, and sphericity is very poor. This and the absence of sedimentary structures indicate that the source region of the sediments may have been nearby.

Clastic rocks of the lithic fragments consist of mediumto fine-grained sandstones and siltstones. The percentage of the clastic rocks varies from 30 to 80 per cent.
The grain size of clastic fragments is always greater than that of volcanic rock fragments. Volcanic rock fragments are always groundmass, with well-preserved, lath-shaped plagioclases. Mafic minerals in these groundmass fragments are few; therefore, these volcanic rocks may be intermediate to acidic volcanic rocks, as are the volcanic rocks of conglomerate underlying the sandstone and siltstone of Unit 5. Metamorphic rock fragments are rarely found in Unit 5. They are pelitic schists, and in some samples schistosity and crenulation cleavage are observed. Limestone fragments were observed in Samples 439-29-2, $74-77 \mathrm{~cm}$. These limestones consist of very fine-grained calcite grains (micrite).

\section{DISCUSSION}

Provenance of the sandstones was an area of clastic rocks, volcanic rocks of intermediate to acidic composition, and small amounts of metamorphic rocks and limestones. This is in accordance with the results of our heavymineral analyses and those of Miki and Takahashi. Such an assemblage of sedimentary rocks, volcanic rocks, and metamorphic rocks is frequently observed in slight- 
TABLE 2

Composition of Sandstone and Modal Analyses of Lithic Fragments, Unit 5, Site 439

\begin{tabular}{|c|c|c|c|c|c|c|c|c|}
\hline $\begin{array}{l}\text { Sample } \\
\text { (interval in } \mathrm{cm} \text { ) }\end{array}$ & Quartz & Feldspar & $\begin{array}{c}\text { Lithic } \\
\text { Fragments }\end{array}$ & Type ${ }^{\mathrm{a}}$ & Clastic & Chert & Volcanic & Metamorphic \\
\hline $439-20-1,70$ & 91.30 & 8.70 & - & W & _- & _- & _ & - \\
\hline $20-1,111$ & 44.44 & 15.87 & 39.68 & W & - & - & - & - \\
\hline $20-1,115-117$ & 35.29 & 29.41 & 35.29 & $\mathrm{~A}$ & 68 & 29 & 1 & 2 \\
\hline $21-1,82$ & 87.50 & 12.50 & - & W & - & - & - & - \\
\hline $21-1,96-97$ & 38.89 & 22.22 & 38.89 & A & 60 & 32 & 5 & 3 \\
\hline $21-1,106$ & 84.62 & 15.38 & - & W & - & - & - & - \\
\hline $21-2,109-111$ & 30.11 & 21.51 & 48.39 & A & 40 & 45 & 10 & 5 \\
\hline $22-2,93$ & 53.33 & 6.67 & 40.00 & W & - & - & - & - \\
\hline $22-2,95$ & 43.18 & 34.09 & 22.73 & W & 50 & 35 & 15 & - \\
\hline $22-3,72-75$ & 38.89 & 27.78 & 33.33 & A & 60 & 40 & - & - \\
\hline $22-5,138$ & 68.49 & 15.07 & 16.44 & A & - & - & - & - \\
\hline $22-6,7-10$ & 34.88 & 18.60 & 46.51 & $\mathrm{~A}$ & 47 & 40 & 3 & - \\
\hline $23-1,27-29$ & 39.02 & 26.83 & 34.15 & W & 60 & 38 & 2 & - \\
\hline $23-1,118$ & 40.00 & 13.33 & 46.67 & W & - & - & - & - \\
\hline $23-3,10-12$ & 43.01 & 26.88 & 30.11 & A & 53 & 37 & 10 & - \\
\hline $24-1,95$ & 40.00 & 26.67 & 33.33 & A & - & - & - & - \\
\hline $24-1,103$ & 40.00 & 26.67 & 33.33 & W & - & - & - & - \\
\hline $24-4,65$ & 40.00 & 13.33 & 46.67 & A & - & - & - & - \\
\hline $24-4,73$ & 40.00 & 13.33 & 46.67 & A & - & - & - & - \\
\hline $24-5,141-143$ & 39.02 & 24.39 & 36.59 & W & 30 & 63 & 7 & - \\
\hline $25-3,74$ & 35.71 & 28.57 & 35.71 & W & - & - & - & - \\
\hline $25-4,8-11$ & 51.55 & 25.77 & 22.68 & A & 50 & 50 & - & - \\
\hline $25-5,83$ & 66.67 & 33.33 & - & W & 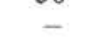 & - & - & - \\
\hline $26-2,92$ & 61.54 & 38.46 & - & W & _- & - & - & - \\
\hline $26-3,77-79$ & 28.57 & 20.41 & 51.02 & A & 64 & 30 & 6 & - \\
\hline $26-4,70$ & 64.29 & 35.71 & - & W & - & - & - & - \\
\hline $26-6,1-4$ & 41.67 & 37.50 & 20.83 & W & 45 & 43 & 12 & - \\
\hline $26-6,95$ & 60.34 & 39.66 & - & W & - & - & - & - \\
\hline $27-2,56$ & 71.43 & 28.57 & - & $\mathrm{A}$ & - & - & - & - \\
\hline $27-2,148-150$ & 33.33 & 27.78 & 38.89 & A & 65 & 15 & 20 & - \\
\hline $27-3,10-12$ & 35.71 & 28.57 & 35.71 & A & 45 & 47 & 8 & - \\
\hline $28-1,56$ & 43.55 & 24.19 & 32.26 & A & - & - & - & - \\
\hline $28-2,49-51$ & 42.55 & 23.40 & 34.04 & A & 38 & 44 & 18 & - \\
\hline $28-3,89$ & 38.96 & 19.48 & 41.56 & A & - & - & - & - \\
\hline $29-1,55$ & 39.47 & 19.74 & 40.79 & A & - & - & - & - \\
\hline $29-2,74-77$ & 30.77 & 21.98 & 47.25 & A & 50 & 44 & 6 & - \\
\hline $29-2,91$ & 37.50 & 18.75 & 43.75 & A & - & - & - & - \\
\hline $30-1,87$ & 38.46 & 15.38 & 46.15 & A & - & - & - & - \\
\hline $30-2,140$ & 55.17 & 27.59 & 17.24 & W & 80 & 16 & 4 & - \\
\hline $31-3,68-70$ & 29.41 & 17.65 & 52.94 & A & 70 & 30 & - & - \\
\hline
\end{tabular}

$\mathrm{a}_{\mathrm{W}}=$ wacke $\mathrm{A}=$ arenite.

TABLE 3

Lithic Fragments in Sandstones of Unit 5, Site 439

\begin{tabular}{|c|c|c|c|c|c|c|c|c|c|}
\hline \multirow[b]{2}{*}{$\begin{array}{c}\text { Sample } \\
\text { (interval in } \mathrm{cm} \text { ) }\end{array}$} & \multirow[b]{2}{*}{$\begin{array}{l}\text { Max. Grain } \\
\text { Size }^{\mathrm{a}}\end{array}$} & \multicolumn{4}{|c|}{ Rock Type } & \multicolumn{4}{|c|}{ Mineral Components } \\
\hline & & $\begin{array}{l}\text { Sandstone- } \\
\text { Siltstone }\end{array}$ & Chert & Volcanic & $\begin{array}{l}\text { Lime- } \\
\text { stone }\end{array}$ & Hor. & $\begin{array}{c}\text { Clino- } \\
\text { pyroxene }\end{array}$ & Biotite & Calcite \\
\hline $439-20-1,113-119$ & 1.47 & 34 & 48 & 18 & - & + & + & + & - \\
\hline $22-3,72-75$ & 0.28 & 48 & 38 & 14 & - & + & - & + & + \\
\hline $22-4,22-25$ & 0.19 & 30 & 47 & 23 & - & - & - & - & - \\
\hline $23-3,10-12$ & 1.68 & 73 & 23 & 4 & - & + & - & - & + \\
\hline $27-2,148-150$ & 0.29 & 30 & 53 & 17 & - & - & - & - & - \\
\hline $29-2,74-77$ & 0.27 & 37 & 50 & 13 & - & + & - & - & + \\
\hline $30-5,{ }^{\mathrm{a}} 8-11$ & - & 43 & 15 & 37 & 5 & - & - & - & - \\
\hline $31-3,68-70$ & 0.59 & 49 & 39 & 8 & 3 & - & - & - & + \\
\hline $31-4,^{\mathrm{a}} 51-53$ & - & 59 & 16 & 22 & 3 & - & - & - & - \\
\hline
\end{tabular}

${ }^{\mathrm{a}}$ Max. grain size $=\sqrt{X Y}$, where $X$ and $Y$ are the longest and shortest diameters.

ly mature modern island arcs along active continental margins. The Oyashio ancient landmass may have been a slightly mature island arc, as also deduced from the chemical compositions of the acidic volcanic rocks underlying the Unit 5 (Fujioka, this volume).
Similar relations have been reported by Matsumoto and Okada (1971) in northwest Hokkaido. According to them, clastic rocks consisting of lithic arenites and (or) lithic wackes of the Upper Cretaceous Yezo Group have many lithic fragments, composed mostly of andesitic to 

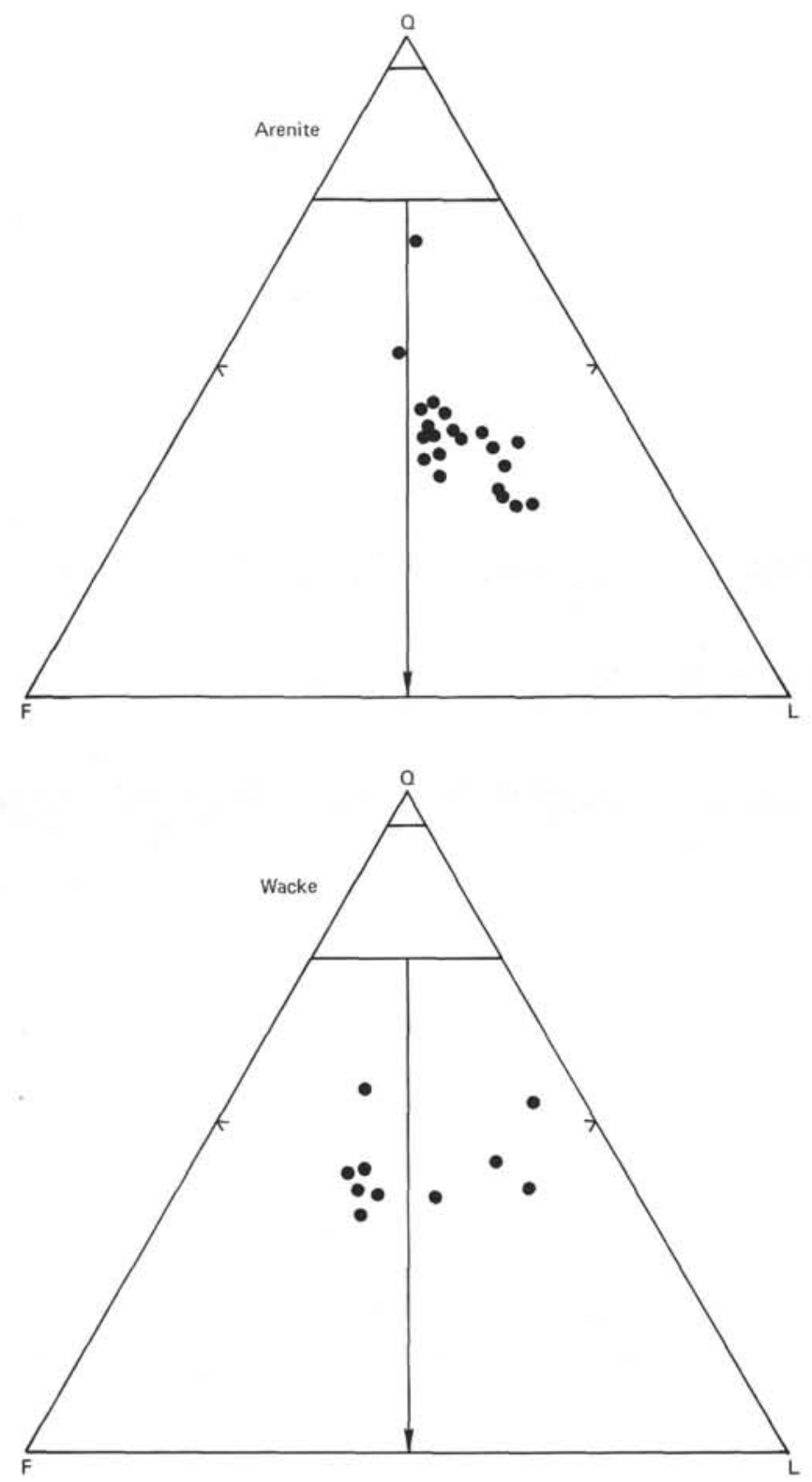

Figure 2. Plots of Site 439 wackes and arenites on $Q F L$ diagrams $(Q, F$, and $L$ represent quartz, feldspar, and lithic fragments, respectively). Boundaries are those of Okada (1971).

rhyolitic volcanic rocks, clastic rocks, and small amounts of plutonic rocks. The sediments of the Yezo Group were derived from a mountain chain to the west, now gone. The Oyashio ancient landmass and Yezo Group have similarities, although different in age, which suggests a genetic relation.

In northeastern Tohoku, the upper Oligocene Noda Group consists of local conglomerates, shallow-water sandstones, and volcanic ash overlying the Upper Cretaceous Kuji Group uncomformably (Sasa, 1932; Shimazu and Teraoka, 1962). The composition of conglomer- ates of the Noda and Kuji Groups were investigated by Nagahama (1977), Terui (1977), and Terui (1978). According to them, conglomerates of the Upper Cretaceous Tamagawa Formation consist mostly of clastic rocks, whereas in the Kunitan Formation they consist of up to 10 per cent of intermediate and basic volcanic rocks and clastics. In the upper Oligocene Minato Formation, conglomerates consist 60 per cent of welded tuff, 20 per cent of acidic volcanic rocks and 20 per cent of clastic rocks. Contents of welded tuff increase upward in the Minato Formation, but in the Kuji Formation, overlying the Minato Formation, the amounts of clastic rocks increase, together with small amounts of hornfels and intermediate to acidic volcanic rocks. Upper Oligocene formations were also reported in Kado area, several kilometers west of the Noda Group outcrops, by Tanai (1978).

Although the age problems remain unsolved, differences in composition of coarse clastic rocks between the Noda Group and Site 439 sediments are obvious. Honza (this volume) suggested a Paleogene paleogeography of the Tohoku region in which a large sedimentary basin separated Site 439 from the Noda region. This may explain the differences.

\section{ACKNOWLEDGMENTS}

The authors wish to thank Drs. Hideo Kagami and Jiro Segawa, Ocean Research Institute, University of Tokyo, for their critical reading of this manuscript. The authors also wish to thank Mr. Terui, Taneichi High School for useful suggestions and kind guidance to the Noda Group.

\section{REFERENCES}

Matsumoto, T., and Okada, H., 1971. Clastic sediments of the Cretaceous Yezo geocyncline. Geol. Soc. Jap. Mem., 6, 6171.

Nagahama, H., 1976. Provenance of the Kuji and the Noda Group estimated from cross beddings and conglomerates. Geol. Soc. Jap. Ann. Mtg. Abs., 84, 333.

1977. Composition of conglomerates and sandstones of the Kuji group and the Noda Group. Geol. Soc. Jap. Ann. Mtg. Abs., 84, 148.

Okada, H., 1971. Classification of sandstone: analysis and proposal. J. Geol., 79, 509-525.

Sasa, Y., 1932. On the geology of the Kuji region, Iwate Prefecture, Japan. Parts 1,2,3. J. Geol. Soc. Jap., 39, 401430, 481-501, 552-580.

Shimazu, M., and Teraoka, Y., 1962. Explanatory text of the geological map of Japan scale 1:50,000 "Rikuchu-Noda": Geological Survey of Japan. [Japanese with English abstract]

Tanai, A., 1978. Late Cretaceous-Paleogene stratigraphy in the environs of the Iwate clay mine, northern Kitakami massif, northeast Japan. J. Geol. Soc. Jap., 84, 459-473.

Terui, K., 1977. On the volcanic rock conglomerates containing moonstone in the Kuji and the Noda Group. Geol. Soc. Jap. Ann. Mtg. Abs., 84, 149.

1978. On the beach conglomerates of volcanic rocks in northern Sanriku shore line. J. Geol. Soc. Jap. Ann. Mtg. Abs., 85, 201.

von Huene, R., and Nasu, N., 1978. Japan Trench transected. Geotimes, 23, 16-21. 
PLATE 1
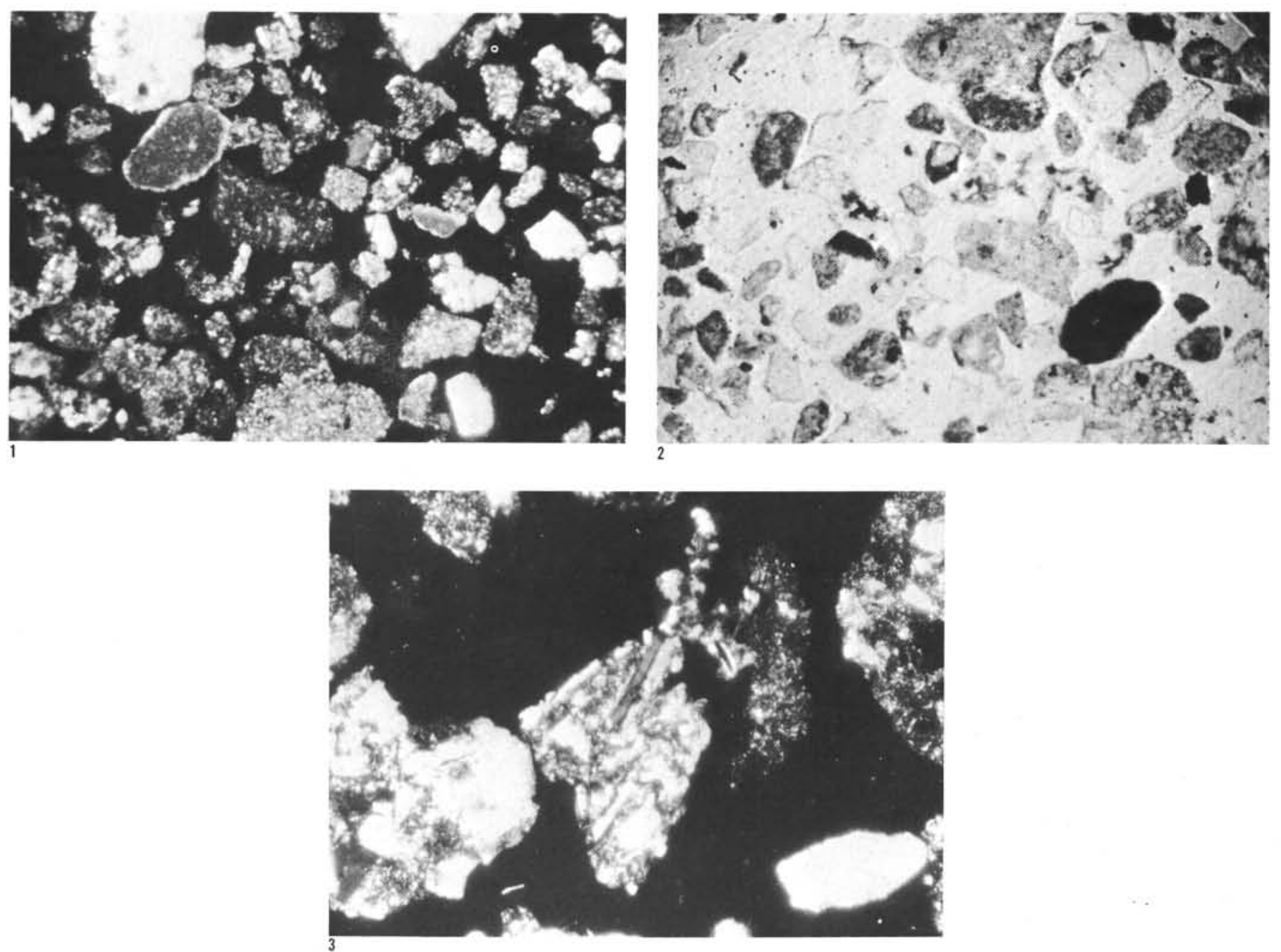

PLATE 1

Thin Sections of Rocks from Unit 5, Site 439

Figure 1 Sample 439-31-3, 68-70 cm. Lithic fragment impregnated with an epoxy resin. Crossed nicols.

Figure 2 Sample 439-31-3, 68-70 cm. Plane light.

Figure 3 Sample 439-31-3, 68-70 cm. Lithic fragment showing groundmass texture of a volcanic rock. Crossed nicols. 